\title{
DIAGNOSTICS OF GASOLINE FUEL SYSTEMS WITH DIRECT INJECTION
}

\author{
M. Bulgakov, Assoc. Prof., Ph. D. (Eng.), \\ Kharkov National Automobile and Highway University
}

\begin{abstract}
A method of diagnosing fuel systems with direct injection by means of producing a pressure oscillation in a hydraulic accumulator is presented. Having obtained a signal from pressure sensor it is possible to register a pressure drop at the moment of injection. If the system has a malfunction, then the pressure drop will be higher.
\end{abstract}

Key words: diagnostics, direct injection, signal, malfuctional, oscillation, pressure sensor, waveform, condition, hydraulic accumulator.

\section{ДІАГНОСТУВАННЯ БЕНЗИНОВИХ ПАЛИВНИХ СИСТЕМ З БЕЗПОСЕРЕДНІМ УПОРСКУВАННЯМ}

\author{
М.П. Булгаков, доц., к.т.н., \\ Харківський національний автомобільно-дорожній університет
}

Анотація. Викладено методику діагностування бензинових паливних систем з безпосереднім упорскуванням палива за падінням тиску в гідроакумуляторі. Показано різні несправності системи й запропоновано метод їх визначення за сигналом штатного датчика тиску. Методика дозволяє проводити експрес-діагностування вузлів.

Ключові слова: діагностування, форсунка, тиск, коливання, датчик.

\section{ДИАГНОСТИРОВАНИЕ БЕНЗИНОВЫХ ТОПЛИВНЫХ СИСТЕМ С НЕПОСРЕДСТВЕННЫМ ВПРЫСКОМ}

\author{
Н.П. Булгаков, доц., к.Т.Н., \\ Харьковский национальный автомобильно-дорожный университет
}

\begin{abstract}
Аннотация. Изложена методика диагностирования бензиновых топливных систем с непосредственным впрыскиванием топлива по падению давления в гидроаккумуляторе. Показаны различные неисправности системы и предложен метод их определения по сигналу штатного датчика давления. Методика позволяет проводить экспресс-диагностирование узлов.
\end{abstract}

Ключевые слова: диагностирование, форсунка, давление, колебание, датчик.

\section{Introduction}

The engine with direct injection of gasoline provides a unique combination of the fuel efficiency coming to the diesel, and the power of the petrol engine.

Engines structurally differ from traditional injector systems quite significantly. First, they can be only multivalvate. In a head of block are almost vertical ports for air supply from an intake mani- fold which provide turbulences of an air flow necessary for the best mixing. Essentially other design of an fuel injectors which allow to inject directly into cylinders, but not in an intake manifold, as usual. Fuel pressure at a stage of injection has to be about 50 bar what in addition to usual the electric fuel pump giving fuel from a tank under the pressure about 3 bar the mechanical fuel pump of high pressure (HP) is used to. It is located directly on the engine. Isn't exist in such engines a throttle in usual sense - the mode 
of behavior of the motor changes depending on amount of fuel in cylinders. And the accelerator pedal in cars performs the transfer command function of electric signal to an electronic control unit. The last, by means of numerous sensors analyzes loads and, depending on a situation, switches to an appropriate program of fuel supply and air.

The engine equipped with a system of direct injection of gasoline in combustion chambers allows to provide exact and low-noise steering of a mixing and combustion even after closing of valves. It allows it to work as at the very poor a fuel-air mixture mode (30-40: 1), what is inaccessible for traditional engines with a manifold injection, and on the enriched mixtures, allows the engine to reach the high power and torque. Besides due to effect of cooling of an air charge, at evaporation of injectable fuel, the filling of cylinders with air is improves. It prevents from detonation and allows to raise an engine compression ratio and consequently also its specific power. Today fuel systems with direct injection of Mitsubishi (GDI) and Volkswagen (FSI) are the most widespread.

\section{Analysis of publications}

The existing systems of fuel supplying in gasoline engines have significant constructive differences. The malfunctions during the using depend on a design of the fuel equipment (FE), the technology of production and service conditions. The analysis of the obtained statistical data on emergence of malfunctions in gasoline engines which are equipped with FSI (fig. 1), showed that the amount of engine failures, take the third place after the traditional and distributive HP equipped with a mechanical adjuster or an electronic control system.

Besides, the significant effect on the atomizer's holes condition has the level of pressure of injection which is much higher in comparison with traditional FE. Despite considerable simplification of a design of HP in FSI, and also because of hypersensibility to quality of fuel and high pressures, the number of malfunctions of HP are higher if to compare to traditional FE.

Reliability of electronics components is higher in the FSI systems because it is refused from sensors which were based on potentiometers and were replaced with sensors which are based on Hall's elements. Limits of temperature stability of basics elements of controllers in a control system were expanded $[1,2]$.

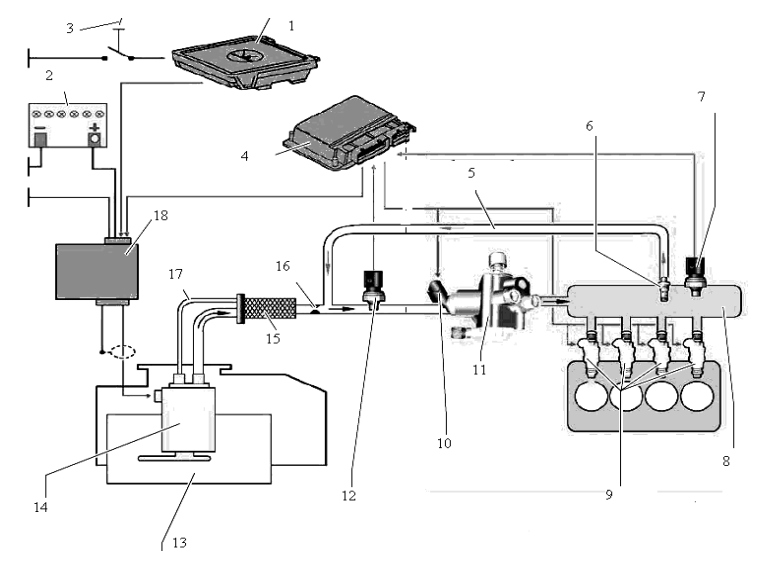

Fig. 1. Scheme of a fuel system of the FSI engine: 1 - the control unit for network, which provides turning on of the electric pump; 2 - rechargeable battery; 3 switcher of the electric pump; 4 - ECU; 5 - the pipe of fuel dumping from rail; 6 - pressure-relief valve; 7 - sensor of high fuel pressure; 8 - rail; 9 - high pressure injectors; 10 - pressure regulator; 11 - high pressure pump; 12 - sensor of a low fuel pressure; 13 - fuel tank; 14 - low pressure electric pump; 15 - the fuel filter with a pressure-relief valve; 16 - throttle; 17 - returns of fuel to a tank; 18 - control unit for the electric pump

The bigger percent of malfunctions with system of Exhaust Gas Recirculation (EGR) is caused by two reasons:

1) because of growing of ecology standards the exhaust gas recirculation system has started to work in wider range of the modes ;

2) specifics of the organization of working process with the late (on TDC) fuel injection and postinjection for providing catalyst converter working, lead to formation of a large amount of black carbon, and quickly disable system of exhaust gas recirculation $[2,3]$. The results of the analysis, which are given, demonstrate that in HP of FSI and injectors most often fail. Thus, it is necessary to develop a complex of the effective methods and the equipments, directed for fault diagnosis, which are arising first of all in these units.

As was shown in literature [4-6] preliminary treatment by means of the diagnostic scanner and of the stand for checking up of injectors and the gas exhaust analyzer, doesn't allow to 
receive necessary reliability of the diagnosis, or is linked with significant expenses of time for dismantling of the fuel equipment and checking it up on the stand.

At modern service stations the requirements to establishing diagnosis are grew and, as a practice showed, decreasing of time expenses with increasing of accuracy of diagnosis is necessary. Any of the listed above methods of diagnosis and the existing techniques doesn't allow to perform these two contradictory requirements completely. The most optimum is the method of rapid diagnosis, and one of its options is offered in this work.

\section{The purpose and problem statement}

During the fuel system working, such units as fuel pump, injectors and fuel regulator pressure (FRP) oscillation are arising in a hydraulic part of system [6]. Analysis of frequency and amplitude these changes allow to define technical condition fuel system's units and about a character of working the aforementioned elements [7].

The aim of the research is to determine the influence of the installation site and the type of pressure sensor on the accuracy of the recording of oscillating processes in the fuel injection system of petrol engine.

To achieve of the goal it is necessary to solve the following tasks:

- to define sensitivity of each sensors to fluctuations of pressure in a fuel rail;

- to define the place for installation of pressure control devices for registration of oscillatory processes.

At modern service stations the requirements to establishing diagnosis are grew and, as a practice showed, decreasing of time expenses with increasing of accuracy of diagnosis is necessary. Any of the listed above methods of diagnosis and the existing techniques doesn't allow to perform these two contradictory requirements completely. The most optimum is the method of rapid diagnosis, and one of its options is offered in this work.

The essence of the offered method consists in the next. The fuel equipment of the gasoline engine represents the balanced system on pressure in a fuel rail. That is, thanks to existence of feedback by means of the pressure control sen- sor in the cars equipped with the GDI system (Mitsubishi), pressure is strictly supported constantly on the level $5 \mathrm{MPa}$. In the cars equipped with the FSI system (VW, Audi, Skoda) pressure is established on the fixed level depending on engine's operation from 5 to $10 \mathrm{MPa}$. At operation of injection a part of fuel, which is equal to the fuel supply per stroke, sharply goes from a fuel rail. Owing to an inertia of a fuel stream, and so far HP didn't increase fuel supply, there is a fuel pressure dropping in a rail proportional to the size of injectable fuel on amplitude This short-termdropping of pressure can be recorded by the on-board pressure control censor. Respectively, if to carry out comparison of amplitudes, pressure decreasing of fuel at operation of each of injection can be compared. It is also possible to compare the amount of fuel passed through each injector. In ideal option on fully functional engine, when receiving the steering impulse of identical duration all 4 injectors have to inject the same amount of fuel. If one of injector has defect, for example, pollution of a flowing part with a resinous deposits, then the size of the fuel delivery per stroke, at the same duration of the steering signal will be less than demanded. And respectively there will be pressure dropping amplitude also be less at the operation of such injector.

If to make measurement of a deviation of a pressure from the standard level of fuel pressure in the rail, that is possible to determine their technical condition using the absolute value of a deviation divided to duration of the steering impulse and in amplitudes of various injectors $[3,4]$. Because the connection of wires of the measuring equipment in two points of the car's wiring (on the plug of injector and on the pressure control device) can be provided quite fast, and dismantling of the fuel equipment for checking up of injectors at the stand can take a lot of time, the offered option should be considered as one of the process elements of express diagnosis. It is important to understand, at the same time, how strong factor, which will influence on the diagnosis, from the electronic control unit. If the fuel supply control algorithm, loaded in the electronic control unit, begins to change duration of the opening impulse, for example, while a signal of lambda sensor changing, then cyclic supply per stroke will increase and at the same time pressure dropping level will return to standard again or will become even more. However, more detailed analysis of the measured signals will allow to obtain the necessary infor- 
mation on technical condition of injectors. Even when compensation of duration of the steering impulse is entered by the electronic control unit it is introdused for all injectors at once. If only one injector is dirty and there is irregular supply of fuel to the cylinders then the total adjustment will not change the picture on the screen of measuring bench will be visible different amplitudes of pressure dropping. Fuel consumption through the injectors can be calculated by the formula:

$$
G=\mu f \cdot \sqrt{2 \rho_{m} \cdot \Delta P} \cdot \tau_{i},
$$

where $\mu f-$ is effective cross section of the injector; $\rho$ - fuel density, $\mathrm{g} / \mathrm{cm}^{3} ; \Delta P$ - pressure difference in an intake manifold and in a fuel rail, $\mathrm{kPa} ; \tau_{i}$ - duration of the steering impulse, ms.

If to accept the following assumptions:

1) the coefficient of compressibility of gasoline isn't considered;

2) influence of temperature of fuel isn't considered.

That it is possible to write down the simplified formula of proportional change of fuel pressure in a fuel rail, depending on fuel supply per stroke:

$$
\frac{\Delta P}{P}=\frac{V}{V_{P}}
$$

where $P-$ is a fuel pressure in a rail, at the time of before injection, $\mathrm{kPa} ; \Delta P$ - is a fuel pressure dropping amplitude at the time of injection, $\mathrm{kPa}$; $V-$ is a rail capacity, $\mathrm{mm}^{3} ; V_{p}-$ is a capacity of fuel supply per stroke, $\mathrm{mm}^{3}$.

Knowing density of fuel, it is possible to calculate mass supply per stroke

$$
G=\rho \cdot V
$$

Then, it is possible to get the simplified equation for determination of size of a fuel dropping pressure, uniting the formulas 1 and 2 :

$$
\Delta P=\frac{P \cdot \mu f \cdot \sqrt{2(\rho)^{3} \cdot \Delta P} \cdot \tau_{i}}{V},
$$

where $P-$ is a fuel pressure in a rail, at the time of before injection, $\mathrm{kPa} ; \mu f-$ is effective cross section of the injector; $\rho$ - fuel density, $\mathrm{g} / \mathrm{cm}^{3}$; $\Delta P$ - pressure difference in an intake manifold and in a fuel rail, $\mathrm{kPa} ; \tau_{i}$ - duration of the steering impulse, $\mathrm{ms} ; V-$ is a rail capacity, $\mathrm{mm}^{3}$.

On the basis of the formulas given above, mathematical modeling of dependence of a fuel pressure dropping to injection duration size was performed (from engine's mods, depending on engine speed and loading).

\section{Results of researching}

If all injectors to supply the same amount of fuel, but less norm, for example, all its are polluted equally. So in this case we can determine their technical condition as well. To do this in parallel with the recording signal of pressure sensor, is being recorded signal duration of injection in an injector. And on the relation of the measured steering signal duration to the written down as a standard, it is possible to determine also the size of correction fuel's supply which were entered by ECU.

On the figure 2 are represented mathematically counted signals of pressure control sensor at injection of each of four injectors. According to a design and the principles of work of the FSI system given above, the four-cam drive gear pusher of a plunger of HP carries out 4 movements of a plunger for one work cycle of the engine.

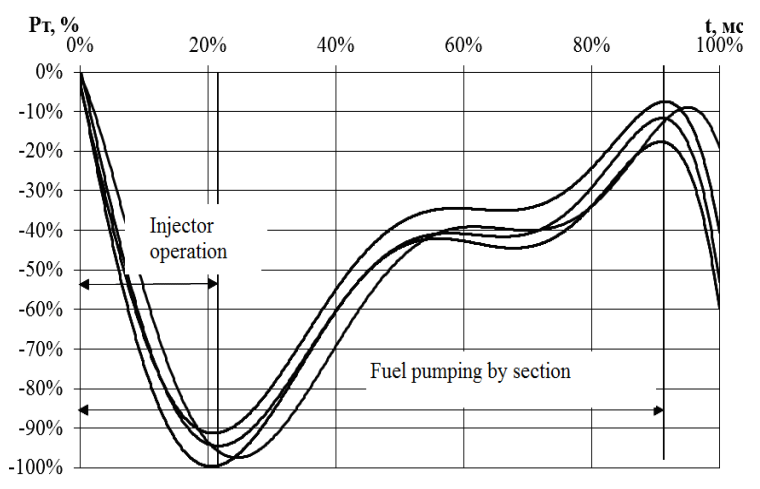

Fig. 2. Relative dropping pressure at injectors working

At the same time the fuel injection by a injector falls on the fuel pumping moment by plunger. fuel pressure at this moment falls (due to blowout of a part of fuel from the fuel rail through the injector). As all 4 injectors are supplyed by one plunger of HP, its influence will be identical to all 4 injections. But at the same time influ- 
ence of each of 4 injectors will be various depending on pollution rate or wear. In the figure 2 it is possible to allocate two parts:

- fuel pressure failure from operation of the injector with simultaneous impact of pumping by fuel plunger couple;

- continuation of pumping of fuel at the closed injector (compensation of a fuel dropping pressure).

At mathematical calculation of a signal of the pressure sensor and pulsations of fuel in a fuel rail it is possible to simulate also failure of one of injector - pollution of the section through passage of a injector by deposits of tar and, as a result, reduction of fuel consumption through it at the same duration of the steering impulse. Results of mathematical calculation for failure are represented on the figure 3 .

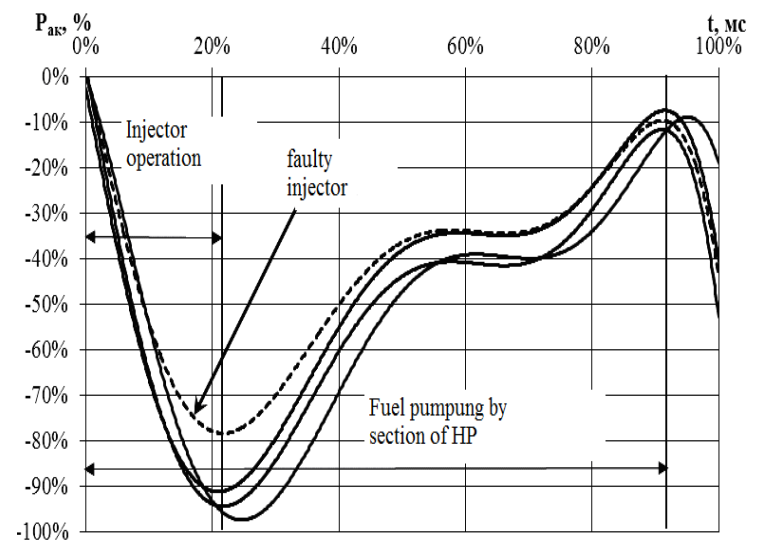

Fig. 3. The simulated failure of one of injector

As during calculation and modeling also actual levels of pressure in fuel to the FSI and GDI equipment weren't considered, duration of fuel injection, calculation was conducted in relative values (percentage of the maximum duration of injection by a injector and the maximum possible amplitude of pressure decrease at injection). In the figure 3 it is seen that the fuel pressure deviation for a faulty injector at failure makes more than $15 \%$ of a deviation of average value on others injectors. In the first case when pressure deviations for serviceable injectors were modelled the dispersion was within $7 \%$.

That is were defined values for a injector at a total deviation of all fields of admissions in one side on increase in the section through passage in a injector and on the other side - on reduction of traverse through passage of a injector.
So at malfunction, the settlement deviation of a signal has to increase at least twice. What theoretically has to allow to define unambiguously failures in an injector.

\section{Conclusions}

Thus, the carried-out modeling showed that the offered method express diagnosis which is based on the analysis of a signal of the pressure control fuel sensor is allows to estimate technical condition of injectors.

\section{References}

1. Системы управления бензиновыми двигателями Bosch. Узлы и агрегаты / перевод с немецкого Н. Понкратова. - М.: ООО «Книжное издательство «За рулём», 2005. - 432 с. - (Первое русское издание).

2. Fox J.A. Transient Flow in Pipes, Open Channels and Sewers Ellis / J.A Fox // Horwood. - 1989. - 284 p.

3. Shaw C.T. Using Computational Fluid Dynamics Prentice Hall / C.T. Shaw // Washington. $-1992 .-315 \mathrm{p}$

4. Chen G. Unsteady multiphase intake flow in a port-injected gasoline engine / G. Chen, S.K. Aggarwal // SAE special publication modeling of SI and CI engines. - 1996. SP-1168. - P. 59-69.

5. Булгаков М.П. Діагностування паливних систем з безпосереднім упорскуванням за коливаннями тиску палива у рампі / М.П. Булгаков // Вісник НТУ «ХПИ»2014. - № 9 (1052). - C. 140-145.

6. Hu Q. Modelling of Dynamic Responses of an Automotive Fuel Rail System, Part I: Injector / Q. Hu, S.F. Wu // Journal of Sound and Vibration. - 2001. - 245 (5). P. 801-814.

7. Ковальчук Л.И. Диагностирование систем топливоподачи бензиновых ДВС по параметрам волновых процессов в топливной рампе / Л.И. Ковальчук, Г.А. Гусев // Автомобильная промышленность. - 2011. - № 4. - C. 25-26.

\section{References}

1. Sistemy upravleniya benzinovymi dvigatelyami Bosch. Uzly i agregaty [Bosch's gasoline engines control system. Units and parts], Za rulem Publ., 2005, 432 p. 
2. Fox J. A. Transient Flow in Pipes, Open Channels and Sewers Ellis, Horwood, 1989, 284 p.

3. Shaw C.T., Using Computational Fluid Dynamics Prentice Hall, Washington, 1992, $315 \mathrm{p}$.

4. G. Chen, S. K. Aggarwal. Unsteady multiphase intake flow in a port-injected gasoline engine, SAE, 1996, pp. 59-69.

5. Bulgakov M.P. Diagnostuvannya palivnikh sistem $z$ bezposerednim uporskuvannyam za kolivannyami tisku paliva u rampi [Diagnosis of fuel systems with direct injection using pressure oscillation], 2014, no. 9 (1052), pp. 140-145.

6. Hu Q. and Wu S.F., Modelling of Dynamic Responses of an Automotive Fuel Rail Sys- tem, Journal of Sound and Vibration, 2001, no. 245 (5), pp. 801-814.

7. Koval'chuk L.I., Gusev G.A. Diagnostirovanie sistem toplivopodachi benzinovykh DVS po parametram volnovykh protsessov $v$ toplivnoy rampe [Diagnosing of fuel suppling systems of petrol CE in parameters of wave processes in a fuel rail], Moskow, Mashinostrenie Publ., 2011, no. 4, pp. 25-26.

Рецензент: В.П. Волков, профессор, д.т.н., ХНАДУ. 